\title{
Mechanisms of Action of Phytochemicals from Medicinal Herbs in the Treatment of Alzheimer's Disease
}

Authors

Affiliations
Mi Hye Kim ${ }^{1}$, Sung-Hoon Kim² , Woong Mo Yang

${ }^{1}$ College of Korean Medicine and Institute of Korean Medicine, Kyung Hee University, Seoul, Korea

${ }^{2}$ Cancer Preventive Material Development Research Center, College of Korean Medicine, Kyung Hee University, Seoul, Korea
Key words

- Alzheimer's disease

- phytochemical

- medicinal herbs

- drug development

\section{Abstract}

$\nabla$

Alzheimer's disease is a chronic neurodegenerative disorder characterized by progressive dementia and deterioration of cognitive function. Although several drugs currently used for the treatment of Alzheimer's disease delay its onset and slow its progression, still there is no drug with profound disease-modifying effects. Studies aiming the treatment of this neurodegenerative disorder explore various disease mechanisms. Since antiquity, medicinal herbs have been used in traditional medicine. Recent studies suggest that the neurobiological effects of phytochemicals from medicinal herbs may contribute to clinical benefits in in vitro and in vivo models of Alzheimer's disease. This review focuses on five phytochemicals, berberine, curcumin, ginsenoside Rg1, puerarin, and silibinin, which have been mostly investigated to treat the development and progression of this neurodegenerative disorder.

\section{Abbreviations}

$\nabla$

AchE: acetylcholinesterase

AD: $\quad$ Alzheimer's disease

Akt: $\quad$ protein kinase $B$

$\mathrm{A} \beta$ : $\quad \beta$-amyloid

APP: $\quad$ amyloid precursor protein

BACE: $\quad \beta$-secretase or beta-site amyloid precursor protein cleaving enzyme

Bax: $\quad$ Bcl-2-associated $X$ protein

Bcl-2: B-cell leukemia protein

BDNF: brain-derived neurotrophic factor

CAT: $\quad$ catalase

Cox: cyclooxygenase

CTF: $\quad$ C terminal fragment

Cyt c: cytochrome c
ELISA: enzyme-linked immunosorbent assay

FDA: $\quad$ Food and Drug Administration

r-GCS: $\quad \gamma$-glutamylcysteine

GFAP: glial fibrillary acidic protein

GRg1: ginsenoside $\operatorname{Rg} 1$

GSH-Px: glutathione peroxidase

GSK3 $\beta$ : $\quad$ glycogen synthase kinase

Iba-1: ionized calcium binding adaptor molecule-1

IL: interleukin

i-Nos: inducible nitric oxide synthase

JNK: c-Jun N-terminal kinase

LDH: lactate dehydrogenase

MAP-2: microtubule-associated protein (MAP)-2

MAPK: mitogen-activated protein kinase signaling

MCP-1: monocyte chemoattractant protein-1

MDA: malondialdehyde

MWM task:Morris water maze task

NF-Kb: nuclear factor- $k \mathrm{~B}$

NICE: National Institute for Health and Clinical Excellence

NO: nitric oxide

p-ERK1/2: extracellular signal-regulated kinase 1 and 2

PI3K: $\quad$ phosphoinositide 3-kinase

PS1: $\quad$ presenilin 1

PTEN: phosphatase and tensin homolog

RAWM: radial arm water maze

RNS: $\quad$ reactive nitrogen species

ROS: $\quad$ reactive oxygen species

SYN: $\quad$ synaptophysin

TEM: transmission electron microscopy

ThT: thioflavin T

(TNF)- $\alpha$ : tumor necrosis factor- $\alpha$

TUNEL: terminal deoxynucleotidyl transferase dUTP nick end labeling 


\section{Introduction}

$\nabla$

$\mathrm{AD}$, a progressive irreversible neurodegenerative disorder characterized by the loss of certain cognitive functions, behavioral disturbances, and daily living difficulties, is the most common form of dementia found among elderly individuals [1]. This disease currently affects 27 million people all over the world [2]. The prevalence rate for AD has become the third greatest threat to the elderly, only behind cardiovascular disease and cancer [3]. Although neither a consensus concerning the pathogenesis of AD nor a perfect therapy for its treatment is available, it is now well accepted that multiple factors, including apoptosis, oxidative stress, excitotoxicity, and the disturbance of energy metabolism homeostasis, contribute to the progression of $\mathrm{AD}$ [4]. Especially, the aggregation and accumulation of extracellular and intracellu$\operatorname{lar} A \beta$ play a critical role in the pathogenesis of $A D$ and result in impaired synaptic plasticity and memory [5]. As a key rate-limiting enzyme, $\alpha-, \beta$-, and $\gamma$-site amyloid precursor protein cleaving enzyme ( $\alpha-, \beta$-, and $\gamma$-secretase) initiates the formation of $\mathrm{A} \beta$ by producing the peptide from APP [6]. APP can be cleaved in two ways, with formation of non-toxic $A \beta_{17-42}$ by $\alpha$ - and $\gamma$-secretases and the generation of toxic $A \beta_{1-42}$ by $\beta$ - and $\gamma$-secretases [7]. Therefore, inhibiting the activity of $\beta$-secretases is important for treating $\mathrm{AD}$ due to their role in the direct cleavage of the $\mathrm{A} \beta$ domain at the N-terminus in APP [8]. These changes are closely associated with tau phosphorylation and PI3K/Akt/GSK3 $\beta$ signaling pathway along with MAPK signaling. The Akt-mediated control of GSK3 $\beta$ activity is involved in tau hyperphosphorylation [9]. $\mathrm{A} \beta$ generated by the cleavage of APP triggers immune responses and activates microglial cells that engulf $A \beta$ filaments, with secretion of various pro-inflammatory factors $[9,10]$. In addition, neuron-related apoptosis and oxidative stress lead to neuronal damage [11].

Numerous in vitro and in vivo models have been used for studying AD. Various types of cells were stimulated with neurodegenerative exposures such as to subtypes of $A \beta$ and acrolein. $\mathrm{A} \beta$ deposition causes synaptic plasticity and memory impairment and has been detected in AD patients at early stage [12]. Acrolein is not only a marker of lipid peroxidation but also an inducer of oxidative stress and an effector of tissue damage [13]. With growing evidence of the implication of acrolein in $\mathrm{AD}$, the development of strategies to reduce its toxic effect is of great importance [12].

Cognitive impairments in animal models are analyzed with behavioral tests, such as MWM task and Y-maze, RAWM, novel object recognition as well as cued and contextual fear-conditioning tests, which are known to be sensitive to hippocampal-dependent learning and memory deficits. Specifically, TgCRND8 mice expressing human APP695 with the Swedish (K670N/M671L) and Indiana (V717F) mutations under regulatory control of the PrP gene promoter (heterozygous with respect to the transgene) on a C57BL/6 F3 background are used to breed the colony of experimental animals [14], while transgenic mouse overexpressing of $\mathrm{APP} / \mathrm{A} \beta$ (Tg mAPP) is a well-used mouse model of $\mathrm{AD}[15,16]$. Despite great effort to discover a remedy for $A D$, no currently available drug can stop or cure this neurodegenerative disorder, and current treatments offer only small symptomatic benefits. The most commonly prescribed drugs are cholinesterase inhibitors such as donepezil, rivastigmine, and galantamine, and NMDA antagonists such as memantine. Though approved by the FDA, these drugs are not recommended by the NICE in England and Wales due to "limited and largely inconclusive" evidence concerning their efficacy [17]. Nootropic agents such as piracetam are commonly prescribed in Europe for the treatment of dementia, including dementia associated with $\mathrm{AD}$, but there are insufficient evidences to verify the efficacy of such drugs [18]. Historically, a number of medicinal herbs have been used to treat neurodegenerative diseases and cognitive disorders in traditional European, Ayurvedic, and Oriental medicines. Medicinal herbs consist primarily of multiple compounds and may influence multiple mechanisms with multi-target functions. This review concerns five phytochemicals, berberine, curcumin, GRg1, puerarin, and silibinin, that have been recently and mostly investigated as alternative treatments for AD and will discuss the advances in our knowledge about these phytochemicals derived from medicinal herbs based on available literature facts collected from books and scientific papers by electronic search (PubMed, ScienceDirect, and Google Scholar) (๑ Fig. 1).

\section{Therapeutic Approaches to Alzheimer's Disease} $\nabla$

\section{Berberine from the cortex of Coptis chinensis}

Berberine, an isoquinoline alkaloid, is one of the major components of Cortex Phellodendri and Rhizoma Coptidis (Coptis chinensis, Franch.; Ranunculaceae). Berberine has been used in herbal medicine for liver disease, skin inflammation, diarrhea, and other disorders due to its anti-diarrheal, anti-microbial, and anti-inflammatory effects [8,19-21]. Specifically, several studies have reported that berberine possesses multiple pharmacological effects that culminate in neuroprotective action against cerebral ischemia, psychological depression, schizophrenia, anxiety, and $\mathrm{AD}[22,23]$. Asai et al. reported that berberine reduces extracellular $A \beta$ production and $B A C E$ activity without changes on release of $\mathrm{LDH}$ in $\mathrm{H} 4$ neuroglioma $\left(\mathrm{APP}_{\mathrm{NL}}-\mathrm{H} 4\right)$ cells [8]. The production of both $A \beta$ and $\beta$-secretase are inhibited by berberine compared with the control in human embryonic kidney 293 (HEK293) cells. Berberine increased the expression level of p-ERK1/2, demonstrating that it may inhibit the production of $A \beta$ via an activation of ERK1/2-induced BACE activity in HEK293 [24].

In another study, the effect of berberine on $A \beta$-induced neuroinflammation was examined in primary and BV2 microglial cells. Pretreatment with berberine reduces $A \beta$-induced IL-6 production and MCP-1 release, as well as expression of Cox-2 and inducible i-Nos. Subsequently, NF- $k B$ and the phosphorylation of I $k \mathrm{~B}-\alpha$, Akt, p38 kinase, and ERK1/2, but not JNK, stimulated by $A \beta$, are regulated following treatment with berberine [25]. Moreover, pretreatment with berberine reduced $A \beta$-stimulated activities of LDH and TNF- $\alpha$ with down-regulation of TNF receptor 1 in SK-N-SH neuroblastoma cells [26].

In APP transgenic mice, berberine treatment improved cognitive impairment as reflected in reductions in errors in the MWM task with respect to both conventional reference memory and memory retention (probe trial). $A \beta$ plaque immunostaining in TgCRND8 mice was associated with reductions in both the number and the area of coronal sections of the cortex and hippocampus following treatment with berberine. Moreover, consistent with the indication that berberine treatment reduces the accumulation of total $\mathrm{A} \beta$ peptides in the brain, a significant reduction was found in the degree of microgliosis by Iba- 1 burden and astrocytosis by GFAP burden. The mechanisms underlying the benefits of berberine on cognitive function and $A \beta$ neuropathology in TgCRND8 mice were expressed for CTF, APP, and tau phosphorylation. An inhibition of PI3K/Akt/GSK3 $\beta$ activities in the TgCRND8 mouse brain 


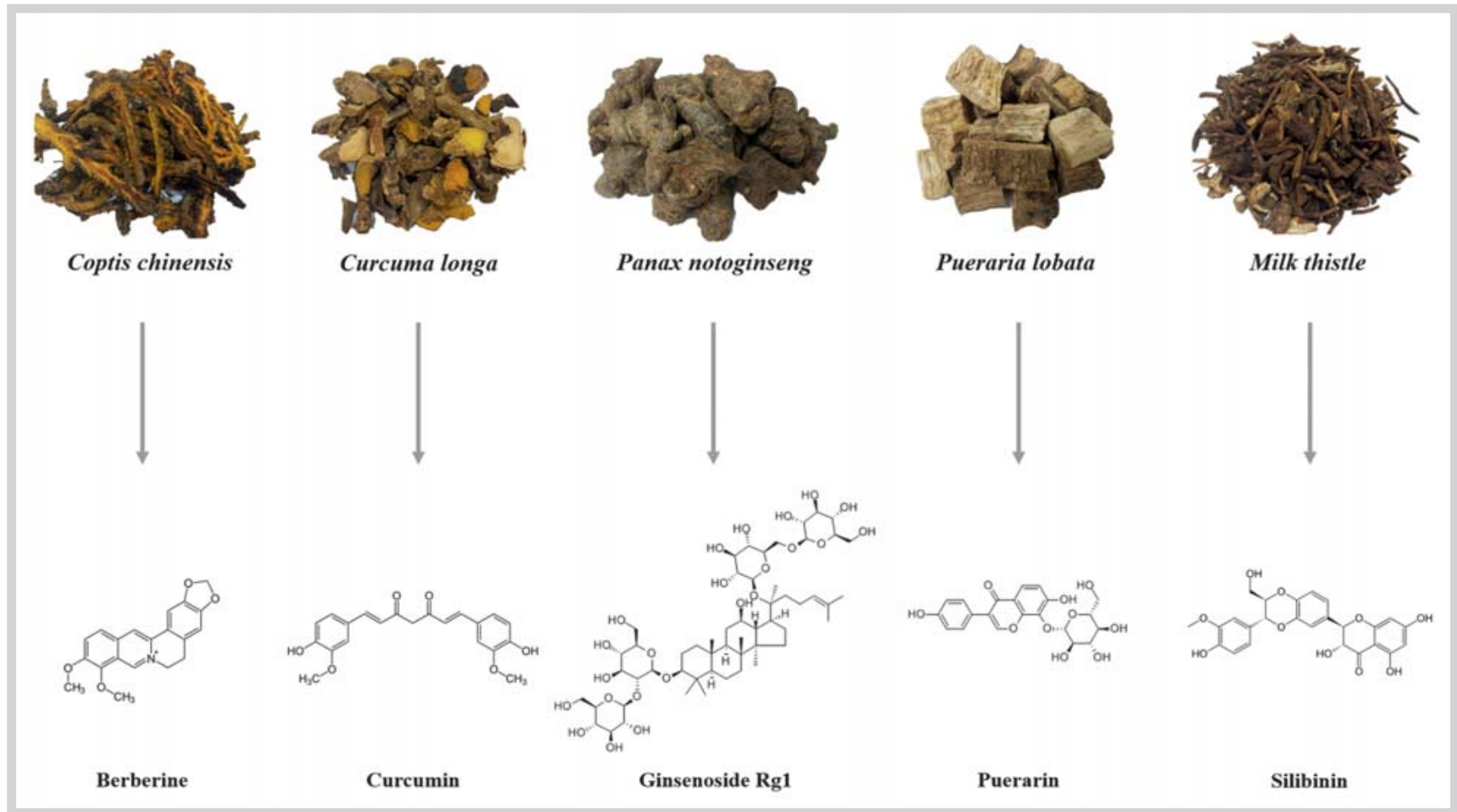

Fig. 1 Chemical structures of phytochemicals from medicinal herbs. (Color figure available online only.)

Table 1 Summary of findings on berberine as alternative treatment for Alzheimer's disease.

\begin{tabular}{|c|c|c|c|}
\hline First author, year [ref] & Study design & Treatments & Results \\
\hline Asai et al., 2006 [17] & $\begin{array}{l}\text { APP }_{\mathrm{NL}}-\mathrm{H} 4 \text { cells } \\
\text { (H4 neuroglioma) }\end{array}$ & $\begin{array}{l}10,20,30,40,50,100 \mu \mathrm{M} \text { berberine } \\
\text { for } 48 \mathrm{~h}\end{array}$ & $\begin{array}{l}\leftrightarrow \text { release of } \mathrm{LDH} \\
\downarrow \beta \text {-secretase activity }\end{array}$ \\
\hline Zhu et al., 2011 [23] & $\begin{array}{l}\text { HEK293 cells (human } \\
\text { embryonic kidney 293) }\end{array}$ & $1,5,10,20 \mu \mathrm{M}$ berberine for $24 \mathrm{~h}$ & $\begin{array}{l}\leftrightarrow \text { cell viability } \\
\leftrightarrow \text { release of } L D H \\
\downarrow \text { extracellular } A \beta_{40 / 42} \text { levels } \\
\downarrow \text { BACE activity } \\
\uparrow \text { phosphorylation of ERK } 1 / 2\end{array}$ \\
\hline Jia et al., 2012 [24] & $\begin{array}{l}\text { Murine primary cells and } \\
\text { microglia cells and cultured } \\
\text { BV2 cells (murine microglia) }\end{array}$ & $\begin{array}{l}\text { Pretreatment of } 1,2.5,5 \mu \mathrm{M} \text { berber- } \\
\text { ine for } 30 \mathrm{~min} \text { and } 20 \mu \mathrm{M} \mathrm{A} \beta_{25-35} \text { for } \\
24 \mathrm{~h}\end{array}$ & $\begin{array}{l}\downarrow \text { IL-6 production and MCP-1 release } \\
\downarrow \text { Cox- } 2 \text { and i-Nos expressions } \\
\downarrow \text { NF- } \mathrm{B} \\
\downarrow \text { phosphorylation of I } \mathrm{B} \text { B- } \alpha \text {, Akt, p38 kinase and ERK1/2 } \\
\leftrightarrow \text { phosphorylation of JNK }\end{array}$ \\
\hline Xu et al., 2013 [25] & $\begin{array}{l}\text { SK-N-SH cell (neuroblasto- } \\
\mathrm{ma} \text { ) }\end{array}$ & $\begin{array}{l}\text { Pretreatment of } 10 \mu \mathrm{M} \text { berberine for } \\
2 \mathrm{~h} \text { and incubation of } 5 \mu \mathrm{M} \mathrm{A} \beta_{25-35} \\
\text { for } 24 \mathrm{~h}\end{array}$ & $\begin{array}{l}\downarrow \text { LDH activity } \\
\downarrow \text { level of TNF- } \alpha \\
\downarrow \text { TNFR1 gene and protein expressions }\end{array}$ \\
\hline Durairajan et al., 2012 [26] & TgCRND8 mice & $\begin{array}{l}\text { Orally administered by gavage once } \\
\text { daily with a } 25 \mathrm{mg} / \mathrm{kg} \text { and } 100 \mathrm{mg} / \\
\mathrm{kg} \text { dose of berberine for } 6 \text { months }\end{array}$ & $\begin{array}{l}\downarrow \text { MWM task } \\
\downarrow \text { number and area of A } \beta \text { plaque } \\
\downarrow \text { lba- } 1 \text { and GFAP burden } \\
\downarrow \text { CTF- } \alpha \text { and }-\beta \text { expression } \\
\downarrow \text { levels of p-APP } \\
\uparrow \text { phosphorylation of Akt at Ser } 473 \text { and GSK3 } \beta \text { at Ser } 21 \\
\text { and Ser9 }\end{array}$ \\
\hline
\end{tabular}

$\uparrow$ Increase; $\downarrow$ decrease; $\leftrightarrow$ no difference

influenced CTF and p-APP levels and led to a blockage of $A \beta$ accumulation [27] ( $\odot$ Table 1).

\section{Curcumin from Curcuma longa}

Curcumin, a hydrophobic polyphenol, is isolated from the rhizome of the herb Curcuma longa L. (Zingiberaceae). It is one of the active components of turmeric involved in antioxidant, antiinflammatory, metal chelators, anti-amyloid, anti-tau, and neu- roprotective activities [13]. In addition, curcumin has been reported to bind to $A \beta$ and prevent aggregation [28] and protect against cell death, as indicated by increased cell viability and decreased TUNEL-positive cells in rat primary neuron cells infected by adeno- 5 virus packaged with iA $\beta_{1-42}$. Curcumin treatment decreased ROS level and protected from intracellular $A \beta$ toxicity [12]. It also inhibited the expression of ROS in acrolein-induced toxicity on SK-N-SH human neuroblastoma cell with increasing 
Table 2 Summary of findings on curcumin as alternative treatment for Alzheimer's disease.

\begin{tabular}{|c|c|c|c|}
\hline First author, year [ref] & Study design & Treatments & Results \\
\hline Ye et al., 2012 [10] & $\begin{array}{l}\text { Rat primary neurons from } \\
\text { new born Sprague-Dawley } \\
\text { rat hippocampus }\end{array}$ & $\begin{array}{l}\text { Infection of by adeno- } 5 \text { virus pack- } \\
\text { aged with iA } \beta_{1-42} \text { and treatment } \\
\text { with } 30 \mu \mathrm{M} \text { curcumin for } 24 \mathrm{~h}\end{array}$ & $\begin{array}{l}\uparrow \text { LDH release } \\
\downarrow \text { TUNEL }{ }^{+} \text {cells } \\
\downarrow \text { stained ROS levels }\end{array}$ \\
\hline Doggui et al., 2013 [11] & $\begin{array}{l}\text { SK-N-SH cell (neuro- } \\
\text { blastoma) }\end{array}$ & $\begin{array}{l}\text { Cotreatment with } 5,10 \text {, or } 20 \mu \mathrm{M} \\
\text { curcumin and acrolein for } 24 \mathrm{~h} \text { and } \\
30 \mathrm{~min}\end{array}$ & $\begin{array}{l}\uparrow \text { LDH release } \\
\uparrow \text { cell survival } \\
\downarrow \text { ROS levels } \\
\downarrow \text {-GCS expression } \\
\downarrow \text { RNS level } \\
\leftrightarrow \text { GSH } \\
\downarrow \text { Nrf2 } \\
\downarrow \text { NF-KB } \\
\downarrow \text { Sirt1 } \\
\uparrow \text { phosphorylation of Akt }\end{array}$ \\
\hline Huang et al., 2013 [28] & $\begin{array}{l}\text { SH-SY5Y cell (human } \\
\text { neuroblastoma) }\end{array}$ & $\begin{array}{l}\text { Treatment with cultured with } 1,5 \text {, or } \\
10 \mathrm{mM} \text { curcumin for } 4 \mathrm{~h} \text { and then } \\
\text { continued incubating with } 10 \mathrm{mM} \\
\mathrm{A} \beta_{1-40} \text { for } 24 \mathrm{~h}\end{array}$ & $\begin{array}{l}\downarrow \text { tau phosphorylation } \\
\uparrow \text { phosphorylation of GSK3 } \beta \text { at Ser9 } \\
\uparrow \text { phosphorylations of Akt at Thr308 and Ser473 } \\
\downarrow \text { up-regulation of PTEN }\end{array}$ \\
\hline Xiong et al., 2011 [29] & $\begin{array}{l}\text { pAPPswe-transfected } \\
\text { SH-SY5Y cell }\end{array}$ & $\begin{array}{l}\text { Treatment with curcumin at } 0,1.25 \text {, } \\
5 \text {, or } 20 \mu \mathrm{M} \text { for } 24 \mathrm{~h} \text {, or at } 5.0 \mu \mathrm{M} \text { for } \\
0,12,24 \text {, or } 48 \mathrm{~h}\end{array}$ & $\begin{array}{l}\downarrow \text { extracellular A } \beta_{40 / 42} \text { levels } \\
\downarrow \text { PS1 mRNA and protein levels } \\
\downarrow \text { GSK3 } \beta \text { mRNA and protein levels }\end{array}$ \\
\hline Hoppe et al., 2013 [30] & Wistar rat & $\begin{array}{l}\text { Intracerebroventricular injection of } \\
\mathrm{A} \beta_{1-42} \text { and after } 2 \text { weeks, adminis- } \\
\text { tration of } 50 \mathrm{mg} / \mathrm{kg} \text { curcumin intra- } \\
\text { peritoneally for } 10 \text { days }\end{array}$ & $\begin{array}{l}\uparrow \text { spontaneous alternation in the Y-maze } \\
\uparrow \text { novel object recognition memory task } \\
\uparrow \text { SYN levels } \\
\downarrow \text { tau phosphorylation } \\
\downarrow \text { TNF- } \alpha \text { and IL- } 1 \beta \\
\downarrow \text { GFAP+ immunocontent levels } \\
\uparrow \text { BDNF } \\
\uparrow \text { phosphorylations of Akt } \\
\uparrow \text { phosphorylation GSK3 } \beta\end{array}$ \\
\hline
\end{tabular}

$\uparrow$ Increase; $\downarrow$ decrease; $\leftrightarrow$ no difference

LDH release. Lipid peroxidation and oxidative stress by acrolein were protected by curcumin treatment. In addition, the expressions of $\gamma$-GCS synthetase and RNS levels, except GSH, were restored by treatment of curcumin. Other oxidative damage marker expressions, such as those of Nrf2, NF-kB, Sirt1, and Akt, were regulated under the presence of curcumin [13].

In other type of human neuroblastoma (SH-SY5Y cells), curcumin treatment decreased $\mathrm{A} \beta$-induced tau phosphorylation at Thr231 and Ser396. In addition, it increased the expression of GSK3 $\beta$ and the phosphorylations of Akt at Thr308 and Ser473 sites and suppressed up-regulation of PTEN [29]. These results were supported by a previous report about the effect of curcumin on production of $A \beta$ in pAPPswe-transfected SH-SY5Y cells. Xiong et al. reported that the production of $A \beta_{40}$ and $A \beta_{42}$ was decreased by treatment with curcumin [29]. Curcumin reduced the activation of PS1 in both mRNA and protein levels in APP-overexpressing cells. This change was accompanied with decreased GSK3 $\beta$ mRNA and protein levels [30].

Furthermore, curcumin has shown beneficial effects through hippocampal-dependent memory improvement. Treatment with curcumin improved the spontaneous alternation behavior as well as the recognition memory task in $\mathrm{A} \beta$-infused rats. Concerning protection of cognitive impairment, a decrease in SYN levels was blocked and the phosphorylation of tau protein in rat hippocampus was decreased under the presence of curcumin. The production of TNF- $\alpha$ and IL- $1 \beta$ and activation of GFAP immunocontent levels were decreased in curcumin-treated hippocampus compared with non-treated samples. Additionally, BDNF concentration and the phosphorylation of Akt and GSK3 $\beta$ revealed an increase after curcumin treatment [31] (๑ Table 2).

\section{Ginsenoside Rg1 from Panax notoginseng}

GRg1, a major active component of Panax notoginseng (Burk.) F.H. Chen (Araliaceae), is used to treat central nervous system dysfunctions, especially those involving cognitive abilities such as learning and memory [32]. The activity of $\beta$-secretase was inhibited in a concentration-dependent manner and a dose-dependent reversal of $A \beta$-induced decreased cell viability was observed following treatment with GRg1 in PC12 cells. GRg1 appeared to prevent oxidative damage through inhibition of LDH efflux, NO production, ROS induction, and lipid peroxidation. Additionally, treatment with GRg1 blocked this $A \beta$-induced calcium increase. To confirm the influence of GRg1 on apoptosis, caspase- 3 activity was investigated by measuring the proteolytic cleavage of the fluorogenic substrate Ac-DEVD-AMC. The $A \beta$-induced increase in caspase- 3 activity was inhibited by treatment with GRg1 [33]. In addition, Li et al. reported that GRg1 displayed anti-A $\beta$ neurotoxicity via p38 pathway activation in SK-N-SH neuroblastoma cells induced by $\mathrm{A} \beta$-stimulated THP- 1 supernatant. Pretreatment with GRg1 markedly decreased LDH leakage, indicating that $A \beta$ induced neuronal injury can be blocked by GRg1. Along with decreased tau phosphorylation, GRg1 treatment resulted in elevated IL-1 $\beta$ and decreased SYN, number of MAP-2 positive cells, and activation of p38 MAPK, which is associated with elevations of phosphorylated tau [34]. In terms of apoptosis, some reports also found that increased cytokine release, including IL-1 $\beta$, IL-8, and TNF- $\alpha$, was inhibited by GRg1 pretreatment in conjunction with an up-regulation of Bcl-2 and a down-regulation of Bax. This, in turn, resulted in an increase in the Bcl-2/Bax ratio as well as a reduction in the activation of caspase-3 [35]. 
Table 3 Summary of findings on ginsenoside $\mathrm{Rg} 1$ as alternative treatment for Alzheimer's disease.

\begin{tabular}{|c|c|c|c|}
\hline First author, year [ref] & Study design & Treatments & Results \\
\hline Wang and Du, 2009 [32] & $\begin{array}{l}\text { PC12 cells (rat pheochromo- } \\
\text { cytoma) }\end{array}$ & $\begin{array}{l}\text { Pretreatment with } 0.1,1,10 \mu \mathrm{M} \mathrm{GRg} 1 \text { for } 1 \mathrm{~h} \text { and } \\
\text { incubation with } 50 \mu \mathrm{M} \mathrm{A} \beta_{25-35} \text { for } 48 \mathrm{~h}\end{array}$ & $\begin{array}{l}\downarrow \text { activity of } \beta \text {-secretase } \\
\downarrow \text { cell survival } \\
\downarrow \text { excessive } \text { LDH efflux } \\
\downarrow \text { excessive generation of NO level } \\
\downarrow \text { ROS generation } \\
\downarrow \text { MDA level } \\
\downarrow \text { rise of }[\text { Ca2 }+] \\
\downarrow \text { caspase- } 3 \text { activity }\end{array}$ \\
\hline Li et al., 2012a [33] & $\begin{array}{l}\text { SK-N-SH neuroblastoma cells } \\
\text { induced by A } \beta \text {-stimulated } \\
\text { THP-1 supernatant }\end{array}$ & $\begin{array}{l}\text { Pretreatment with } 50,100 \text { and } 150 \mu \mathrm{M} \mathrm{GRg} 1 \text { for } \\
30 \text { min and then incubation with } 125 \mathrm{nM} \mathrm{A} \beta_{1-40}\end{array}$ & $\begin{array}{l}\downarrow \text { LDH leakage } \\
\downarrow \text { tau-phosphorylation } \\
\downarrow \text { content of IL- } 1 \beta \text { release } \\
\uparrow \text { MAP-2 expression } \\
\uparrow \text { SYN expression } \\
\downarrow \text { phosphorylation of p38 }\end{array}$ \\
\hline Li et al., 2012b [34] & $\begin{array}{l}\text { SK-N-SH neuroblastoma cells } \\
\text { induced by A } \beta \text {-stimulated } \\
\text { THP-1 supernatant }\end{array}$ & $\begin{array}{l}\text { Pretreatment with } 50,100 \text {, and } 150 \mu \mathrm{M} \mathrm{GRg} 1 \text { for } \\
30 \text { min and then incubation with } 125 \mathrm{nM} \mathrm{A} \beta_{1-40} \text { for } 2 \mathrm{~h}\end{array}$ & $\begin{array}{l}\downarrow \text { LDH release } \\
\downarrow \text { levels of IL- } 1 \beta \text {, IL-8, and TNF- } \alpha \\
\downarrow \text { TUNEL-positive cells } \\
\downarrow \text { annexin } V \text {-FITC } \\
\uparrow \text { ratio of Bcl-2/Bax } \\
\downarrow \text { caspase-3 expression }\end{array}$ \\
\hline Huang et al., 2012 [35] & $\begin{array}{l}\text { Cortical neurons from } \\
\text { C57BL/6 mouse fetuses }\end{array}$ & $\begin{array}{l}\text { Pretreatment with } G R g 1 \text { for } 24 \mathrm{~h} \text {, and then incubation } \\
\text { with } 5 \mu \mathrm{M} \mathrm{A} \beta_{1-42} \text { for } 48 \mathrm{~h}\end{array}$ & $\begin{array}{l}\downarrow \text { Cyt c release from mitochondria } \\
\downarrow \text { TUNEL } L^{+} \text {neurons } \\
\downarrow \text { activity of caspase-3 }\end{array}$ \\
\hline Wu et al., 2012 [36] & $\begin{array}{l}\text { Cortical neurons from em- } \\
\text { bryonic (E18d) rat fetus }\end{array}$ & $\begin{array}{l}\text { Pretreatment with } 1,10,20 \mu \mathrm{M} \mathrm{GRg} 1 \text { for } 24 \mathrm{~h} \text { and } \\
\text { incubation with } 10 \text { with } 10 \mu \mathrm{M} \mathrm{A} \beta_{25-35} \text { for } 72 \mathrm{~h}\end{array}$ & $\begin{array}{l}\uparrow \text { cell viability } \\
\uparrow \text { Bcl-2/Bax ratio } \\
\downarrow \text { release of Cyt c } \\
\downarrow \text { caspase- } 9 \\
\downarrow \text { caspase-3 }\end{array}$ \\
\hline Gong et al., 2011 [37] & $\begin{array}{l}\text { Primary cultured hippocam- } \\
\text { pal neurons from embryonic } \\
\text { brains of Wistar rats }\end{array}$ & $\begin{array}{l}\text { Pretreatment with } 1 \mathrm{mg} / \mathrm{mL} \mathrm{A} \beta_{25-35} \text { for } 7 \text { days and } \\
\text { incubation with GRg1 } 0.1,1,10 \mu \mathrm{M} \text { for } 72 \mathrm{~h}\end{array}$ & $\begin{array}{l}\uparrow \text { cell viability } \\
\downarrow \text { LDH release } \\
\downarrow \text { annexin } \mathrm{V}^{+} / \mathrm{PI}^{-} \text {fraction } \\
\uparrow \text { Bcl- } 2 / \text { Bax ratio } \\
\downarrow \text { caspase-3 }\end{array}$ \\
\hline Fang et al., 2012 [38] & $\begin{array}{l}\text { Tg mAPP (transgenic mice } \\
\text { with neuronal overexpres- } \\
\text { sion of a mutant human form } \\
\text { of amyloid precursor pro- } \\
\text { tein) }\end{array}$ & $\begin{array}{l}\text { Four experimental groups: } \\
\text { (1) non } \mathrm{Tg} \text { with vehicle-treated group } \\
\text { (2) non } \mathrm{Tg} \text { with } 1 \mathrm{mg} / \mathrm{kg} \text { GRg1-treated group } \\
\text { (3) } \mathrm{Tg} \mathrm{mAPP} \text { with vehicle-treated group } \\
\text { (4) } \mathrm{Tg} \mathrm{mAPP} \text { with } 1 \mathrm{mg} / \mathrm{kg} \text { GRg1-treated group }\end{array}$ & 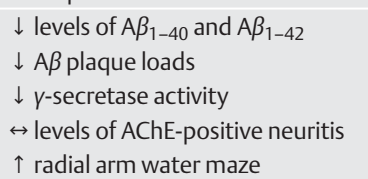 \\
\hline
\end{tabular}

$\uparrow$ Increase; $\downarrow$ decrease; $\leftrightarrow$ no difference

In addition, GRg1-treated cortical neurons from C57BL/6 mouse fetuses with $A \beta_{1-42}$ inhibited the expression of Cyt $c$ in cytosolic fraction, whereas Cyt c levels in mitochondrial fractions were increased. Marked decrease in caspase-3 activity and TUNEL-positive apoptotic neurons were shown in GRg1-treated groups [36]. In cortical neurons from embryonic rat fetus, GRg1 treatment protected $A \beta_{25-35}$-induced cell death. Bcl-2/Bax ratio was increased with reduced caspase- 9 and -3 activities by GRg1 treatment. Release Cyt c from mitochondria was blocked with GRg1 treatment [37]. Similarly, increased LDH release was suppressed against cytotoxicity of $A \beta_{25-35}$ under the presence of GRg1. GRg1 reduced the numbers of apoptotic cells, as shown in decreased annexin $\mathrm{V}^{+} / \mathrm{PI}^{-}$fraction. The ratio of $\mathrm{Bcl}-2 / \mathrm{Bax}$ was up-regulated and activation of caspase- 3 was down-regulated by GRg1 treatment [38].

In an animal study, Fang et al. demonstrated the neuroprotective effects of GRg1 in transgenic AD mice. ELISA and immunostaining with an $A \beta$ antibody revealed that $A \beta$ plaque loads were lower in the cerebral cortex and hippocampus of GRg1-treated mAPP mice than in vehicle-treated mice. This lower accumulation of $A \beta$ in the cortices of GRg1-treated mice stemmed from the inhibition of $\gamma$-secretase activity and did not affect levels of AChE- positive neurites in the entorhinal cortex. Compared with vehicle-treated mAPP mice, GRg1-treated mice were shown to improve their performance in RAWM task [39] ( Table 3).

\section{Puerarin from the radix of Pueraria lobata}

Previous research has demonstrated that puerarin (from Pueraria lobata (Willd.) Ohwi.; Fabaceae), which has been widely used in traditional medicine for thousands of years, exhibits anti-oxidant, anti-myocardial, anti-ischemic retinopathy, and anti-hyperglycemic effects $[40,41]$. Zou et al. reported that puerarin have a protective effect against $A \beta$-induced neurotoxicity in rat hippocampal neurons via various mechanisms. Pretreatment with puerarin decreased $A \beta$-induced cell death in cultured rat hippocampal neurons by inhibiting GSK-3 $\beta$ via activation of Akt [42]. Furthermore, puerarin treatment resulted in an increase in GSH-Px and CAT activities and a decrease in the production of ROS [43].

In addition, treatment with puerarin prevented $A \beta_{25-35}$-induced apoptosis, as a result of decrease of TUNEL-positive cells and annexin $\mathrm{V}^{+} / \mathrm{PI}^{-}$fraction. Puerarin-treated cells inhibited the expression of caspase-3 with increased expression of Bcl-2 and decreased expression of Bax [44]. Similarly, Zhang et al. demon- 
Table 4 Summary of findings on puerarin as alternative treatment for Alzheimer's disease.

\begin{tabular}{|c|c|c|c|}
\hline First author, year [ref] & Study design & Treatments & Results \\
\hline Zou et al., 2013 [41] & $\begin{array}{l}\text { Primary cultured hippo- } \\
\text { campal neurons from } \\
\text { Sprague - Dawley rats }\end{array}$ & $\begin{array}{l}\text { Pretreatment with } 3,10,30,100 \mu \mathrm{M} \text { puerarin for } \\
2 \text { hours and addition with } 20 \mu \mathrm{M} \mathrm{A} \beta_{25-35} \text { for } 24 \mathrm{~h}\end{array}$ & $\begin{array}{l}\uparrow \text { cell viability } \\
\downarrow \text { ROS levels } \\
\uparrow \text { phosphorylation of GSK3 } \beta \text { at Ser9 }\end{array}$ \\
\hline Lin et al., 2012 [42] & $\begin{array}{l}\text { Primary cultured hippo- } \\
\text { campal neurons from } \\
\text { Sprague - Dawley rats }\end{array}$ & $\begin{array}{l}\text { Pretreatment with } 3,10,30,100 \mu \mathrm{M} \text { puerarin for } \\
2 \text { hours and addition with } 20 \mu \mathrm{M} \mathrm{A} \beta_{25-35} \text { for } 24 \mathrm{~h}\end{array}$ & $\begin{array}{l}\uparrow \text { cell viability } \\
\downarrow \text { GSK3 } \beta \text { activity } \\
\uparrow \text { phosphorylation of Akt } \\
\uparrow \text { level of GSH-Px } \\
\uparrow \text { level of CAT activity }\end{array}$ \\
\hline Zhang et al., 2008 [43] & $\begin{array}{l}\text { PC12 cells (rat pheochro- } \\
\text { mocytoma) }\end{array}$ & $\begin{array}{l}\text { Preincubation with } 0.1,1 \text {, and } 10 \mu \mathrm{M} \text { puerarin for } \\
30 \text { min and addition with } 50 \mu \mathrm{M} \mathrm{A} \beta_{25-35} \text { for } 24 \mathrm{~h}\end{array}$ & $\begin{array}{l}\uparrow \text { cell viability } \\
\downarrow \text { TUNEL-positive cells } \\
\downarrow \text { annexin } \mathrm{V}^{+} / \mathrm{Pl}^{-} \text {fraction } \\
\uparrow \text { expression of Bcl-2 } \\
\downarrow \text { expression of Bax } \\
\downarrow \text { caspase-3 }\end{array}$ \\
\hline Zhang et al., 2011 [44] & $\begin{array}{l}\text { mitochondrial transgenic } \\
\text { neuronal cell used Rho } \\
\text { SH-SY5Y cells lacking } \\
\text { mtDNA }\end{array}$ & $\begin{array}{l}\text { Treatment with } 0.1,1 \text {, and } 10 \mu \mathrm{M} \text { puerarin for } 24 \\
\text { hours }\end{array}$ & $\begin{array}{l}\uparrow \text { cell viability of SAD cybrids } \\
\downarrow \text { annexin } \mathrm{V}^{+} / \mathrm{Pl}^{-} \text {fraction } \\
\downarrow \text { intracellular ROS generation } \\
\uparrow \text { expression of } \mathrm{Bcl}-2 \\
\downarrow \text { expression of } \mathrm{Bax} \\
\downarrow \text { phosphorylation of JNK and p38 } \\
\downarrow \text { caspase- } 3 \text { activity }\end{array}$ \\
\hline Li et al., 2010 [45] & Male Sprague-Dawley rats & $\begin{array}{l}\text { Intracerebroventricular injection of } 10 \mu \mathrm{g} / \mu \mathrm{L} A \beta_{1-42} \\
\text { and after } 3 \text { days, orally administration by gavage with } \\
\text { puerarin for } 28 \text { days; Six experimental groups: } \\
\text { (1) sham-operated group } \\
\text { (2) saline-treated } A \beta_{1-42} \text { group } \\
\text { (3) donepezil-treated } A \beta_{1-42} \text { group } \\
\text { (4) } 25 \mathrm{mg} / \mathrm{kg} \text { puerarin-treated } A \beta_{1-42} \text { group } \\
\text { (5) } 50 \mathrm{mg} / \mathrm{kg} \text { puerarin-treated } A \beta_{1-42} \text { group } \\
\text { (6) } 25 \mathrm{mg} / \mathrm{kg} \text { puerarin-treated } A \beta_{1-42} \text { group }\end{array}$ & $\begin{array}{l}\downarrow \text { MWM task } \\
\uparrow \text { number of crossings over a platform } \\
\text { position } \\
\downarrow \text { TUNEL-positive cells } \\
\uparrow \text { phosphorylation of Akt-ser } 473 \text { and } \\
\text {-Bad levels } \\
\leftrightarrow \text { unchange on total Akt and Bad levels } \\
\downarrow \text { caspase-9 protein and mRNA levels }\end{array}$ \\
\hline
\end{tabular}

$\uparrow$ Increase; $\downarrow$ decrease; $\leftrightarrow$ no difference

strated that puerarin protected against cybrid viability loss in mitochondrial transgenic neuronal cells. Annexin $\mathrm{V}^{+} / \mathrm{PI}^{-}$fraction and intracellular ROS levels were attenuated by puerarin treatment. In addition, the expression of Bax, Bcl-2, phosphorylation of JNK and p38 were regulated by treatment of puerarin [45]. Another study found that puerarin treatment resulted in a significant enhancement of MWM task against $A \beta$ injection. Treatment with puerarin decreased $A \beta$-induced cell death in rat hippocampus via activation of Akt. Furthermore, the phosphorylation of Bad was increased, while the production of caspase- 9 was decreased in puerarin-treated group [46] (๑ Table 4).

\section{Silibinin from the herb milk thistle (Silybum marianum)} Silibinin is a flavonoid derived from the herb milk thistle (Silybum marianum (L.) Gaertn.; Asteraceae) and is known to have anti-oxidative and anti-inflammatory properties [47]. Various studies have indicated that silibinin confers protection against oxidative stress in hepatocytes by decreasing lipid peroxidation, a sensitive marker of oxidative lipids and scavenging of free radicals $[48,49]$. Silibinin is protective against $A \beta$-induced oxidative stress in SH-SY5Y human neuroblastoma cells. The aggregation of $A \beta$ was markedly inhibited following treatment with silibinin in ThT binding assay and TEM imaging assay. The presence of silibinin with $A \beta$ increased cell viability, whereas its absence decreased it. Additionally, the level of $\mathrm{H}_{2} \mathrm{O}_{2}$ in $\mathrm{A} \beta$-treated cells decreased following incubation with silibinin [50].

In animal experiments, silibinin ameliorates $A \beta$-induced shortterm memory impairment as measured by a spontaneous alternation behavior task (Y-maze test) although no significant differ- ences in the number of spontaneous locomotor activities were observed. Recognition memory in novel object recognition tests was improved by silibinin in $A \beta$-injected mice, while the amounts of time spent exploring objects in training and retention sessions did not differ. To further explore the effects of silibinin on $A \beta$-induced oxidative stress, levels of MDA and GSH were analyzed. Treatment with silibinin appeared to decrease MDA levels and increase GSH levels in the hippocampus [51]. The cued freezing response and contextual freezing response were attenuated in silibinin-treated animals, indicating an impairment in associative memory. However, silibinin did not change the level of response to electric foot shock (flinching, vocalization, and jumping) in either group. A significant increase in nitrotyrosine, TNF- $\alpha$, and i-Nos levels in the hippocampus and amygdala were reduced following treatment with silibinin compared with distilled water [52] (๑ Table 5).

\section{Discussion}

$\nabla$

The aggregation and accumulation of extracellular and intracellular $A \beta$ induce impaired synaptic plasticity and memory [4]. Three proteases, such as $\alpha-, \beta$-, and $\gamma$-secretases, cleave APP and generate the physiological peptide $A \beta$ along with increased production of CTFs [53-55]. These soluble peptides spontaneously aggregate to form $A \beta$ oligomers and fibrils that are subsequently deposited within the brain to form amyloid plaques [56]. The intracerebroventricular administration of $A \beta$ peptide induces histological and biochemical changes, memory deficits, oxidative 
Table 5 Summary of findings on silibinin as alternative treatment for Alzheimer's disease.

\begin{tabular}{|c|c|c|c|}
\hline First author, year [ref] & Study design & Treatments & Results \\
\hline Yin et al., 2010 [49] & $\begin{array}{l}\text { SH-SY5Y cells (human } \\
\text { neuroblastoma) }\end{array}$ & $\begin{array}{l}\text { Pretreatment of } 0,2.5,5,10,20,50 \mu \mathrm{M} \text { silibinin and } \\
\text { addition with } 100 \mu \mathrm{M} \mathrm{A} \beta_{1-42} \text { for } 24 \mathrm{~h}\end{array}$ & $\begin{array}{l}\downarrow \text { ThT binding assay } \\
\downarrow \mathrm{A} \beta_{1-42} \text { aggregation } \\
\downarrow \text { cytotoxicity of } \mathrm{A} \beta_{1-42} \\
\downarrow \text { level of } \mathrm{H}_{2} \mathrm{O}_{2}\end{array}$ \\
\hline Lu et al., 2009a [51] & Male ICR mice & $\begin{array}{l}\text { Intracerebroventricular injection of } 3 \mathrm{nmol} / \text { mouse } \\
A \beta_{25-35} \text { and after } 4 \text { days, orally administration by gavage } \\
\text { with silibinin for } 11 \text { days; Six experimental groups: } \\
\text { (1) vehicle-treated group } \\
\text { (2) vehicle-treated } A \beta_{25-35} \text { group } \\
\text { (3) } 2 \mathrm{mg} / \mathrm{kg} \text { silibinin-treated } A \beta_{25-35} \text { group } \\
\text { (4) } 20 \mathrm{mg} / \mathrm{kg} \text { silibinin-treated } A \beta_{25-35} \text { group } \\
\text { (5) } 200 \mathrm{mg} / \mathrm{kg} \text { silibinin-treated } A \beta_{25-35} \text { group } \\
\text { (6) } 200 \mathrm{mg} / \mathrm{kg} \text { silibinin-treated group }\end{array}$ & $\begin{array}{l}\leftrightarrow \text { no significant differences in the time } \\
\text { course and total of locomotor activity } \\
\uparrow \text { impairment of spontaneous alterna- } \\
\text { tion behaviour } \\
\uparrow \text { level of exploration preference in the } \\
\text { retention session } \\
\downarrow \text { level of MDA } \\
\uparrow \text { level of GSH }\end{array}$ \\
\hline Lu et al., 2009b [52] & Male ICR mice & $\begin{array}{l}\text { Intracerebroventricular injection of } 3 \mathrm{nmol} / \text { mouse } \\
A \beta_{25-35} \text { and after } 4 \text { days, orally administration by gavage } \\
\text { with silibinin for } 8 \text { days; Eight experimental groups: } \\
\text { (1) vehicle-treated group } \\
\text { (2) vehicle-treated } A \beta_{25-35} \text { group } \\
\text { (3) } 2 \mathrm{mg} / \mathrm{kg} \text { silibinin-treated } A \beta_{25-35} \text { group } \\
\text { (4) } 20 \mathrm{mg} / \mathrm{kg} \text { silibinin-treated } A \beta_{25-35} \text { group } \\
\text { (5) } 200 \mathrm{mg} / \mathrm{kg} \text { silibinin-treated } A \beta_{25-35} \text { group } \\
\text { (6) } 2 \mathrm{mg} / \mathrm{kg} \text { silibinin-treated group } \\
\text { (7) } 20 \mathrm{mg} / \mathrm{kg} \text { silibinin-treated group } \\
\text { (8) } 200 \mathrm{mg} / \mathrm{kg} \mathrm{silibinin-treated} \mathrm{group}\end{array}$ & $\begin{array}{l}\uparrow \text { cued and contextual freezing re- } \\
\text { sponses } \\
\leftrightarrow \text { no differences on the levels of electric } \\
\text { current required to elicit flinching, } \\
\text { vocalization, and jumping } \\
\uparrow \text { nitrotyrosine levels in the hippocam- } \\
\text { pus and amygdala } \\
\downarrow \text { i-Nos and TNF- } \alpha \text { mRNA expression }\end{array}$ \\
\hline
\end{tabular}

$\uparrow$ Increase; $\downarrow$ decrease; $\leftrightarrow$ no difference

damage, and inflammatory responses [4,5]. Based on our review, berberine, GRg1, and silibinin appear to block the formation of $A \beta$ via an inhibition of $\beta$-secretase activity. In addition, GRg1 suppressed $\gamma$-secretase activity.

The PI3K/Akt/GSK3 $\beta$ signaling pathway is associated with various aspects of $A D$ pathology. PI3K regulates the trafficking of intracellular APP-CTFs, whereas GSK modulates APP processing and thereby influences the production of $A \beta$ in neurons. Inhibition of PI3K contributes to tau phosphorylation and impairment in spatial memory. Suppressing GSK3 activity, which is induced by phosphorylation at specific serine residues (Ser 9 and Ser21) by Akt, has been demonstrated to contribute to the accumulation of $A \beta$ in APP mice and the hyperphosphorylation of tau protein [57-62]. Berberine, curcumin, and puerarin regulated the PI3K/ Akt/GSK3 $\beta$ signaling pathway. Berberine increased the phosphorylation of Akt and GSK3 $\beta$, resulting in decreases of APP-CTFs levels. In vitro and in vivo data demonstrated that curcumin exhibits significant increases in the phosphorylation of Akt and GSK3 $\beta$. Puerarin also upregulated the phosphorylation of GSK3 $\beta$ and Akt. The activation of glial cells and the expression of inflammatory mediators in conjunction with the presence of neurotoxic free radicals lead to neuroinflammation. Activated microglial cells induced by $A \beta$ are able to engulf filament $A \beta$; thus, the decrease in the Iba- 1 burden correlates with a reduced plaque burden [6365]. Release of proinflammatory cytokines, such as IL-6, IL- $1 \beta$, and TNF- $\alpha$, along with chemokines is responsible for the initiation and progression of inflammatory responses [66-68]. Several studies have shown that IL- 6 induces the processing of APP and regulates $A \beta$ production [69]. Microglia and macrophages are a major source of TNF- $\alpha$ although TNF- $\alpha$ is also expressed to a lesser extent by GFAP-positive astrocytes, and IL- $1 \beta$ is expressed by neurons and astrocytes in response to AD-like pathology [66, 67]. High level of MCP-1 promotes the migration and recruitment of inflammatory cells $[70,71]$. Furthermore, $A \beta$-induced MCP-1
mRNA expression is associated with the activation of the PI3K/ Akt signaling pathway [72]. Additionally, NF- $k B$, and its key inhibitor, I $k \mathrm{~B}-\alpha$, primary regulator of inflammatory processes in almost all cell types including neurons, are expressed in microglial cells that express i-Nos and Cox-2 [73,74]. Previous studies have shown that the MAPK signaling pathways play an important role in the regulation of chemokine and pro-inflammatory cytokine production in microglia $[75,76]$. Berberine, curcumin, and GRg1 suppressed the activation of microglial cells and neuroinflammation by blocking the production of proinflammatory cytokines. Berberine, GRg1, and puerarin inhibited NF- $k$ B and MAPK signaling pathways. In particular, berberine decreased the Iba- 1 burden, indicating a reduction in the degree of microgliosis. In addition, treatment with berberine reduced IL- 6 production and MCP-1 release in microglial cells. and suppressed NF- $k$ B translocation into the nucleus as well as the phosphorylation of $\mathrm{I} k \mathrm{~B}-\alpha$, ERK1/2, and p38. Curcumin treatment showed a significant decrease in activated microglia along with reductions in IL- $1 \beta$ and TNF- $\alpha$. In case of GRg 1 , the content of IL- $1 \beta$, IL- 8 , and TNF- $\alpha$ were reduced with the phosphorylation of $\mathrm{p} 38$. And puerarin attenuated the phosphorylation of JNK and p38, resulting in the protection against neuronal cell death.

Concerning neuron cell survival, the loss of neuron-related apoptosis is regulated by several intracellular signaling events [77]. During early apoptosis stages, the Bcl-2 protein family which includes anti-apoptotic molecules such as Bcl-2 and $\mathrm{Bcl}_{-\mathrm{xL}}$ and proapoptotic molecules such as Bax, Bak, Bid, and Bad, is related to the formation of channels in mitochondrial membranes. The Bcl2/Bax ratio, in particular, is crucial for initiating apoptosis, and its translocation to the mitochondrial membrane may lead to the loss of mitochondrial membrane potential and increased mitochondrial permeability [78] which results in the release of Cyt c from mitochondria and the subsequent activation of procaspase3 to caspase-3, eventually leading to apoptosis [79]. GRg1 and 
puerarin attenuated apoptosis by regulating anti-apoptotic and pro-apoptotic molecules. GRg1 regulated the ratio of Bcl-2/Bax, resulting in the release of $\mathrm{Cyt} \mathrm{c}$ from mitochondria and the reduction of caspase- 9 and caspase- 3 activities. Puerarin protected cell death via up-regulating the ratio of Bcl-2/Bax and down-regulating the caspase- 9 and -3 activities which were induced by the phosphorylation of Bad.

Furthermore, it is well established that oxidative stress is involved in apoptosis in that excessive production of ROS can lead to neuronal apoptosis in AD $[11,80]$. GSH and MDA are important intracellular anti-oxidants necessary for the formation of peroxynitrite and responsible for removing oxygen-free radicals [51, 81]. In addition, the activations of NF- $k$ B, Sirt1, and Nrf2 pathways are related to protection of cells against oxidant damage as stress sensor molecules [82]. Curcumin, GRg1, puerarin, and silibinin exhibited protection against oxidative stress. Specifically, curcumin regulated $\gamma$-GCS expression and RNS level. And treatment with GRg1 inhibited the excessive generation of NO and MDA levels as well as ROS generation. Puerarin also decreased intracellular ROS generation while increasing GSH-Px and CAT activities in various neuronal cells. Silibinin decreased the levels of MDA, whereas GSH was increased in in vivo study.

Apart from the pathology, memory enhancement is one of major issues of AD. Loss of neuroblasts and markers, characteristic of striatal medium spiny neurons, belong to the process of neuronal cell death [83]. In terms of neurotrophic factors, BDNF promotes the survival of new hippocampal neurons [84]. Synaptic proteins take part in the development of nerve synapses and adjust their plasticity. SYN, one of the synaptic proteins, is a marker of synaptic distribution and synaptic density [85]. GRg1 increased SYN expression, and curcumin contributed to the formation of new neurons by regulating the synaptic proteins SYN and BDNF.

To date, evidence from recent studies suggests that commonly used medicinal herbs and their phytochemicals could potentially be used to treat AD. Although these studies focus on the efficacy of inhibiting AD development, and research on humans is limited, numerous findings demonstrate the possibilities of the use of medicinal herbs for the treatment of AD. The approach to investigate the potential treatment of $A D$ may support drug development from herbal medicine.

\section{Acknowledgements}

$\nabla$

This work was supported by the National Research Foundation of Korea (NRF) grant funded by the Korea government [MEST] (No. 2012-0005 755).

\section{Conflict of Interest}

$\nabla$

The authors state no conflict of interest.

\section{References}

1 Burns A, Zaudig M. Mild cognitive impairment in older people. Lancet 2002; 360: 1963-1965

2 Novakovic D, Feligioni M, Scaccianoce S, Caruso A, Piccinin S, Schepisi C, Errico F, Mercuri NB, Nicoletti F, Nistico R. Profile of gantenerumab and its potential in the treatment of Alzheimer's disease. Drug Des Devel Ther 2013; 7: 1359-1364

3 Yan H, Li L, Tang XC. Treating senile dementia with traditional Chinese medicine. Clin Interv Aging 2007; 2: 201-208
4 Sinha S, Anderson JP, Barbour R, Basi GS, Caccavello R, Davis D, Doan M, Dovey HF, Frigon N, Hong J, Jacobson-Croak K, Jewett N, Keim P, Knops J, Lieberburg I, Power M, Tan H, Tatsuno G, Tung J, Schenk D, Seubert P, Suomensaari SM, Wang S, Walker D, Zhao J, McConlogue L, John V. Purification and cloning of amyloid precursor protein beta-secretase from human brain. Nature 1999; 402: 537-540

5 Vassar R, Bennett BD, Babu-Khan S, Kahn S, Mendiaz EA, Denis P, Teplow $D B$, Ross S, Amarante P, Loeloff R, Luo Y, Fisher S, Fuller J, Edenson S, Lile J, Jarosinski MA, Biere AL, Curran E, Burgess T, Louis JC, Collins F, Treanor J, Rogers G, Citron M. Beta-secretase cleavage of Alzheimer's amyloid precursor protein by the transmembrane aspartic protease BACE. Science 1999; 286: 735-741

6 Yankner BA, Lu T. Amyloid beta-protein toxicity and the pathogenesis of Alzheimer disease. J Biol Chem 2009; 284: 4755-4759

7 De Strooper B, Vassar R, Golde T. The secretases: enzymes with therapeutic potential in Alzheimer disease. Nat Rev Neurol 2010; 6: 99-107

8 Asai M, Iwata N, Yoshikawa A, Aizaki Y, Ishiura S, Saido TC, Maruyama K. Berberine alters the processing of Alzheimer's amyloid precursor protein to decrease Abeta secretion. Biochem Biophys Res Commun 2007; 352: 498-502

9 Roychaudhuri R, Yang M, Hoshi MM, Teplow DB. Amyloid beta-protein assembly and Alzheimer disease. J Biol Chem 2009; 284: 4749-4753

10 Mrak RE, Griffin WS. Glia and their cytokines in progression of neurodegeneration. Neurobiol Aging 2005; 26: 349-354

11 Matsuoka Y, Picciano M, La Francois J, Duff K. Fibrillar beta-amyloid evokes oxidative damage in a transgenic mouse model of Alzheimer's disease. Neuroscience 2001; 104: 609-613

$12 \mathrm{Ye} \mathrm{J}$, Zhang Y. Curcumin protects against intracellular amyloid toxicity in rat primary neurons. Int J Clin Exp Med 2012; 5: 44-49

13 Doggui S, Belkacemi A, Paka GD, Perrotte M, Pi R, Ramassamy C. Curcumin protects neuronal-like cells against acrolein by restoring Akt and redox signaling pathways. Mol Nutr Food Res 2013; 57: 1660-1670

14 Chishti MA, Yang DS, Janus C, Phinney AL, Horne P, Pearson J, Strome R, Zuker N, Loukides J, French J, Turner S, Lozza G, Grilli M, Kunicki S, Morissette C, Paquette J, Gervais F, Bergeron C, Fraser PE, Carlson GA, George-Hyslop PS, Westaway D. Early-onset amyloid deposition and cognitive deficits in transgenic mice expressing a double mutant form of amyloid precursor protein 695. J Biol Chem 2001; 276: 2156221570

15 Mucke L, Masliah E, Yu GQ, Mallory M, Rockenstein EM, Tatsuno G, Hu K, Kholodenko D, Johnson-Wood K, McConlogue L. High-level neuronal expression of abeta 1-42 in wild-type human amyloid protein precursor transgenic mice: synaptotoxicity without plaque formation. J Neurosci 2000; 20: 4050-4058

16 Caspersen C, Wang N, Yao J, Sosunov A, Chen X, Lustbader JW, Xu HW, Stern D, McKhann G, Yan SD. Mitochondrial Abeta: a potential focal point for neuronal metabolic dysfunction in Alzheimer's disease. FASEB J 2005; 19: 2040-2041

17 Kmietowicz Z. NICE proposes to withdraw Alzheimer's drugs from NHS. BMJ 2005; 330: 495

18 Flicker L, Grimley Evans G. Piracetam for dementia or cognitive impairment. Cochrane Database Syst Rev 2001; CD001011

19 Stermitz FR, Lorenz P, Tawara JN, Zenewicz LA, Lewis K. Synergy in a medicinal plant: antimicrobial action of berberine potentiated by $5^{\prime}$ methoxyhydnocarpin, a multidrug pump inhibitor. Proc Natl Acad Sci U S A 2000; 97: 1433-1437

20 Kuo CL, Chi CW, Liu TY. The anti-inflammatory potential of berberine in vitro and in vivo. Cancer Lett 2004; 203: 127-137

21 Sack RB, Froehlich JL. Berberine inhibits intestinal secretory response of Vibrio cholerae and Escherichia coli enterotoxins. Infect Immun 1982; 35: 471-475

22 Kim KW, Ha KT, Park CS, Jin UH, Chang HW, Lee IS, Kim CH. Polygonum cuspidatum, compared with baicalin and berberine, inhibits inducible nitric oxide synthase and cyclooxygenase- 2 gene expressions in RAW 264.7 macrophages. Vascul Pharmacol 2007; 47: 99-107

23 Hu JP, Nishishita K, Sakai E, Yoshida H, Kato Y, Tsukuba T, Okamoto K. Berberine inhibits RANKL-induced osteoclast formation and survival through suppressing the NF-kappaB and Akt pathways. Eur J Pharmacol 2008; 580: 70-79

24 Zhu F, Wu F, Ma Y, Liu G, Li Z, Sun Y, Pei Z. Decrease in the production of beta-amyloid by berberine inhibition of the expression of beta-secretase in HEK293 cells. BMC Neurosci 2011; 12: 125

25 Jia L, Liu J, Song Z, Pan X, Chen L, Cui X, Wang M. Berberine suppresses amyloid-beta-induced inflammatory response in microglia by inhib- 
iting nuclear factor-kappaB and mitogen-activated protein kinase signalling pathways. J Pharm Pharmacol 2012; 64: 1510-1521

$26 \mathrm{Xu}$ J, Zhang $H$, Yang F, Yu JX. [Intervention effect of berberine on expressions of TNF-alpha and receptor type I in Abeta25-35-induced inflammatory reaction in SH-SY5Y cell lines]. Zhongguo Zhong Yao Za Zhi 2013; 38: 1327-1330

27 Durairajan SS, Liu LF, Lu JH, Chen LL, Yuan Q, Chung SK, Huang L, Li XS, Huang JD, Li M. Berberine ameliorates beta-amyloid pathology, gliosis, and cognitive impairment in an Alzheimer's disease transgenic mouse model. Neurobiol Aging 2012; 33: 2903-2919

28 Reinke AA, Gestwicki JE. Structure-activity relationships of amyloid beta-aggregation inhibitors based on curcumin: influence of linker length and flexibility. Chem Biol Drug Des 2007; 70: 206-215

29 Huang HC, Tang $D$, Xu K, Jiang ZF. Curcumin attenuates amyloid-betainduced tau hyperphosphorylation in human neuroblastoma SH-SY5Y cells involving PTEN/Akt/GSK-3beta signaling pathway. J Recept Signal Transduct Res 2014; 34: 26-37

30 Xiong Z, Hongmei Z, Lu S, Yu L. Curcumin mediates presenilin-1 activity to reduce beta-amyloid production in a model of Alzheimer's Disease. Pharmacol Rep 2011; 63: 1101-1108

31 Hoppe JB, Coradini K, Frozza RL, Oliveira CM, Meneghetti AB, Bernardi A, Pires ES, Beck RC, Salbego CG. Free and nanoencapsulated curcumin suppress beta-amyloid-induced cognitive impairments in rats: involvement of BDNF and Akt/GSK-3beta signaling pathway. Neurobiol Learn Mem 2013; 106: 134-144

32 Chang Y, Huang WJ, Tien LT, Wang SJ. Ginsenosides Rg1 and Rb1 enhance glutamate release through activation of protein kinase $A$ in rat cerebrocortical nerve terminals (synaptosomes). Eur J Pharmacol 2008; 578: 28-36

33 Wang $Y H, D u G H$. Ginsenoside Rg1 inhibits beta-secretase activity in vitro and protects against Abeta-induced cytotoxicity in PC12 cells. J Asian Nat Prod Res 2009; 11: 604-612

34 Li W, Chu Y, Zhang L, Yin L, Li L. Ginsenoside Rg1 attenuates tau phosphorylation in SK-N-SH induced by Abeta-stimulated THP-1 supernatant and the involvement of p 38 pathway activation. Life Sci 2012; 91 : 809-815

35 Li W, Chu Y, Zhang L, Yin L, Li L. Ginsenoside Rg1 prevents SK-N-SH neuroblastoma cell apoptosis induced by supernatant from Abeta1-40stimulated THP-1 monocytes. Brain Res Bull 2012; 88: 501-506

36 Huang T, Fang F, Chen L, Zhu Y, Zhang J, Chen X, Yan SS. Ginsenoside Rg1 attenuates oligomeric Abeta(1-42)-induced mitochondrial dysfunction. Curr Alzheimer Res 2012; 9: 388-395

37 Wu JY, Shen YY, Zhu WJ, Chen MY, Wang ZQ Liu Y, Zhu DY, Lou YJ. [Ginsenoside Rg1 antagonizes beta-amyloid peptide-induced apoptosis in primarily cultured rat neurons via mitochondrial pathway]. Zhejiang Da Xue Xue Bao Yi Xue Ban 2012; 41: 393-401

38 Gong L, Li SL, Li H, Zhang L. Ginsenoside Rg1 protects primary cultured rat hippocampal neurons from cell apoptosis induced by beta-amyloid protein. Pharm Biol 2011; 49: 501-507

39 Fang F, Chen X, Huang T, Lue LF, Luddy JS, Yan SS. Multi-faced neuroprotective effects of Ginsenoside Rg1 in an Alzheimer mouse model. Biochim Biophys Acta 2012; 1822: 286-292

40 Qicheng F. Some current study and research approaches relating to the use of plants in the traditional Chinese medicine. J Ethnopharmacol 1980; 2: 57-63

41 Fan LL, Sun LH, Li J, Yue XH, Yu HX, Wang SY. The protective effect of puerarin against myocardial reperfusion injury. Study on cardiac function. Chin Med J (Engl) 1992; 105: 11-17

42 Zou Y, Hong B, Fan L, Zhou L, Liu Y, Wu Q Zhang X, Dong M. Protective effect of puerarin against beta-amyloid-induced oxidative stress in neuronal cultures from rat hippocampus: involvement of the GSK-3beta/Nrf2 signaling pathway. Free Radic Res 2013; 47: 55-63

43 Lin F, Xie B, Cai F, Wu G. Protective effect of Puerarin on beta-amyloidinduced neurotoxicity in rat hippocampal neurons. Arzneimittelforschung 2012; 62: 187-193

44 Zhang $H Y$, Liu YH, Wang HQ Xu JH, Hu HT. Puerarin protects PC12 cells against beta-amyloid-induced cell injury. Cell Biol Int 2008; 32: 12301237

45 Zhang H, Liu Y, Lao M, Ma Z, Yi X. Puerarin protects Alzheimer's disease neuronal cybrids from oxidant-stress induced apoptosis by inhibiting pro-death signaling pathways. Exp Gerontol 2011; 46: 30-37

46 Li J, Wang G, Liu J, Zhou L, Dong M, Wang R, Li X, Li X, Lin C, Niu Y. Puerarin attenuates amyloid-beta-induced cognitive impairment through suppression of apoptosis in rat hippocampus in vivo. Eur J Pharmacol 2010; 649: 195-201
47 Gazak R, Walterova D, Kren V. Silybin and silymarin-new and emerging applications in medicine. Curr Med Chem 2007; 14: 315-338

48 Youn CK, Park SJ, Lee MY, Cha MJ, Kim OH, You HJ, Chang IY, Yoon SP, Jeon YJ. Silibinin inhibits LPS-induced macrophage activation by blocking p 38 MAPK in RAW 264.7 cells. Biomol Ther (Seoul) 2013; 21: 258-263

49 Trouillas P, Marsal P, Svobodova A, Vostalova J, Gazak R, Hrbac J, Sedmera $P$, Kren V, Lazzaroni R, Duroux JL, Walterova D. Mechanism of the antioxidant action of silybin and 2, 3-dehydrosilybin flavonolignans: a joint experimental and theoretical study. J Phys Chem A 2008; 112: 1054-1063

50 Yin F, Liu J, Ji X, Wang Y, Zidichouski J, Zhang J. Silibinin: a novel inhibitor of Abeta aggregation. Neurochem Int 2011; 58: 399-403

51 Lu P, Mamiya T, Lu LL, Mouri A, Zou L, Nagai T, Hiramatsu M, Ikejima T, Nabeshima T. Silibinin prevents amyloid beta peptide-induced memory impairment and oxidative stress in mice. Br J Pharmacol 2009; 157: 1270-1277

52 Lu P, Mamiya T, Lu LL, Mouri A, Niwa M, Hiramatsu M, Zou LB, Nagai T, Ikejima $T$, Nabeshima T. Silibinin attenuates amyloid beta(25-35) peptide-induced memory impairments: implication of inducible nitric-oxide synthase and tumor necrosis factor-alpha in mice. J Pharmacol Exp Ther 2009; 331: 319-326

53 Fassbender K, Simons M, Bergmann C, Stroick M, Lutjohann D, Keller P, Runz H, Kuhl S, Bertsch T, von Bergmann K, Hennerici M, Beyreuther K, Hartmann T. Simvastatin strongly reduces levels of Alzheimer's disease beta-amyloid peptides Abeta 42 and Abeta 40 in vitro and in vivo. Proc Natl Acad Sci U S A 2001; 98: 5856-5861

54 Xiu J, Nordberg A, Qi X, Guan ZZ. Influence of cholesterol and lovastatin on alpha-form of secreted amyloid precursor protein and expression of alpha7 nicotinic receptor on astrocytes. Neurochem Int 2006; 49: 459465

55 Famer D, Crisby M. Rosuvastatin reduces caspase-3 activity and up-regulates alpha-secretase in human neuroblastoma SH-SY5Y cells exposed to A beta. Neurosci Lett 2004; 371: 209-214

56 Nawrot B. Targeting BACE with small inhibitory nucleic acids - a future for Alzheimer's disease therapy? Acta Biochim Pol 2004; 51: 431-444

57 Frame S, Cohen P. GSK3 takes centre stage more than 20 years after its discovery. Biochem J 2001; 359: 1-16

58 Chang KA, Kim HS, Ha TY, Ha JW, Shin KY, Jeong YH, Lee JP, Park CH, Kim S, Baik TK, Suh YH. Phosphorylation of amyloid precursor protein (APP) at Thr668 regulates the nuclear translocation of the APP intracellular domain and induces neurodegeneration. Mol Cell Biol 2006; 26: 4327-4338

59 Judge M, Hornbeck L, Potter H, Padmanabhan J. Mitosis-specific phosphorylation of amyloid precursor protein at threonine 668 leads to its altered processing and association with centrosomes. Mol Neurodegener 2011; 6: 80

60 Martin D, Salinas M, Lopez-Valdaliso R, Serrano E, Recuero M, Cuadrado A. Effect of the Alzheimer amyloid fragment Abeta(25-35) on Akt/PKB kinase and survival of PC12 cells. J Neurochem 2001; 78: 1000-1008

61 Phiel CJ, Wilson CA, Lee VM, Klein PS. GSK-3alpha regulates production of Alzheimer's disease amyloid-beta peptides. Nature 2003; 423: 435439

62 Jaworski T, Dewachter I, Lechat B, Gees M, Kremer A, Demedts $D_{\text {, }}$ Borghgraef P, Devijver H, Kugler S, Patel S, Woodgett JR, Van Leuven F. GSK-3alpha/beta kinases and amyloid production in vivo. Nature 2011; 480: E4-5; discussion E6

63 Nimmerjahn A, Kirchhoff F, Helmchen F. Resting microglial cells are highly dynamic surveillants of brain parenchyma in vivo. Science 2005; 308: 1314-1318

64 McGeer EG, McGeer PL. Inflammatory processes in Alzheimer's disease. Prog Neuropsychopharmacol Biol Psychiatry 2003; 27: 741-749

65 Sasaki Y, Ohsawa K, Kanazawa H, Kohsaka S, Imai Y. Iba1 is an actincross-linking protein in macrophages/microglia. Biochem Biophys Res Commun 2001; 286: 292-297

66 Bhat RV, DiRocco R, Marcy VR, Flood DG, Zhu Y, Dobrzanski P, Siman R, Scott $R$, Contreras PC, Miller M. Increased expression of IL-1beta converting enzyme in hippocampus after ischemia: selective localization in microglia. J Neurosci 1996; 16: 4146-4154

67 McGeer PL, McGeer EG. The inflammatory response system of brain: implications for therapy of Alzheimer and other neurodegenerative diseases. Brain Res Brain Res Rev 1995; 21: 195-218

68 Banati RB, Gehrmann J, Schubert P, Kreutzberg GW. Cytotoxicity of microglia. Glia 1993; 7: 111-118 
69 Hull M, Strauss S, Berger M, Volk B, Bauer J. The participation of interleukin-6, a stress-inducible cytokine, in the pathogenesis of Alzheimer's disease. Behav Brain Res 1996; 78: 37-41

70 Peterson PK, Hu S, Salak-Johnson J, Molitor TW, Chao CC. Differential production of and migratory response to beta chemokines by human microglia and astrocytes. J Infect Dis 1997; 175: 478-481

71 Kelder W, McArthur JC, Nance-Sproson T, McClernon D, Griffin DE. Betachemokines MCP-1 and RANTES are selectively increased in cerebrospinal fluid of patients with human immunodeficiency virus-associated dementia. Ann Neurol 1998; 44: 831-835

72 Ito S, Sawada M, Haneda M, Ishida Y, Isobe K. Amyloid-beta peptides induce several chemokine mRNA expressions in the primary microglia and Ra2 cell line via the PI3K/Akt and/or ERK pathway. Neurosci Res 2006; 56: 294-299

73 Bi W, Zhu L, Wang C, Liang Y, Liu J, Shi Q Tao E. Rifampicin inhibits microglial inflammation and improves neuron survival against inflammation. Brain Res 2011; 1395: 12-20

74 Pan XD, Chen XC, Zhu YG, Chen LM, Zhang J, Huang TW, Ye QY, Huang HP. Tripchlorolide protects neuronal cells from microglia-mediated betaamyloid neurotoxicity through inhibiting NF-kappaB and JNK signaling. Glia 2009; 57: 1227-1238

75 Maezawa I, Zimin PI, Wulff H, Jin LW. Amyloid-beta protein oligomer at low nanomolar concentrations activates microglia and induces microglial neurotoxicity. J Biol Chem 2011; 286: 3693-3706

76 Zhou Y, Ling EA, Dheen ST. Dexamethasone suppresses monocyte chemoattractant protein-1 production via mitogen activated protein kinase phosphatase- 1 dependent inhibition of Jun N-terminal kinase and p38 mitogen-activated protein kinase in activated rat microglia. J Neurochem 2007; 102: 667-678
$77 \mathrm{Du}$ C, Hu R, Csernansky CA, Hsu CY, Choi DW. Very delayed infarction after mild focal cerebral ischemia: a role for apoptosis? J Cereb Blood Flow Metab 1996; 16: 195-201

78 Yang J, Liu X, Bhalla K, Kim CN, Ibrado AM, Cai J, Peng TI, Jones DP, Wang X. Prevention of apoptosis by Bcl-2: release of cytochrome $\mathrm{c}$ from mitochondria blocked. Science 1997; 275: 1129-1132

79 Kluck RM, Bossy-Wetzel E, Green DR, Newmeyer DD. The release of cytochrome c from mitochondria: a primary site for Bcl-2 regulation of apoptosis. Science 1997; 275: 1132-1136

80 Li MH, Jang JH, Sun B, Surh YJ. Protective effects of oligomers of grape seed polyphenols against beta-amyloid-induced oxidative cell death. Ann N Y Acad Sci 2004; 1030: 317-329

81 Aksenov MY, Markesbery WR. Changes in thiol content and expression of glutathione redox system genes in the hippocampus and cerebellum in Alzheimer's disease. Neurosci Lett 2001; 302: 141-145

82 Dang TN, Arseneault M, Zarkovic N, Waeg G, Ramassamy C. Molecular regulations induced by acrolein in neuroblastoma SK-N-SH cells: relevance to Alzheimer's disease. J Alzheimers Dis 2010; 21: 1197-1216

83 Masliah E, Mallory M, Alford M, DeTeresa R, Hansen LA, McKeel DW jr., Morris JC. Altered expression of synaptic proteins occurs early during progression of Alzheimer's disease. Neurology 2001; 56: 127-129

84 Schulte-Herbruggen O, Braun A, Rochlitzer S, Jockers-Scherubl MC, Hell$w e g$. Neurotrophic factors-a tool for therapeutic strategies in neurological, neuropsychiatric and neuroimmunological diseases? Curr Med Chem 2007; 14: 2318-2329

85 Gincel D, Shoshan-Barmatz V. The synaptic vesicle protein synaptophysin: purification and characterization of its channel activity. Biophys J 2002; 83: 3223-3229 